\title{
Bioaccumulation of Total and Methyl Mercury in Three Earthworm Species (Drawida sp., Allolobophora sp., and Limnodrilus sp.)
}

\author{
Zhong Sheng Zhang • Dong Mei Zheng • \\ Qi Chao Wang · Xian Guo Lv
}

Received: 7 April 2009/Accepted: 9 September 2009/Published online: 25 September 2009

(C) The Author(s) 2009. This article is published with open access at Springerlink.com

\begin{abstract}
We determined total and methyl mercury contents in soil, three earthworm species and their vomitus to study the species-specific differences of mercury bioconcentration in Huludao City, a heavily polluted region by chlor-alkali and nonferrous metal smelting industry in Liaoning Province, northeast China. Total and methyl mercury contents were $7.20 \mathrm{mg} / \mathrm{kg}$ and $6.94 \mathrm{ng} / \mathrm{g}$ in soil, $1.43 \mathrm{mg} / \mathrm{kg}$ and $43.03 \mathrm{ng} / \mathrm{g}$ in Drawida sp., $2.80 \mathrm{mg} / \mathrm{kg}$ and $336.52 \mathrm{ng} / \mathrm{g}$ in Alolobophora sp., respectively. Total mercury contents were $0.966 \mathrm{mg} / \mathrm{kg}$ in Drawida sp. vomitus and $4.979 \mathrm{mg} / \mathrm{kg}$ in Alolobophora sp. vomitus, respectively. Total mercury contents in earthworms and their vomitus were significantly species-specific different and were both in decreasing with earthworms body lengths, which might due to the growth dilution. Among the soil, earthworms and their vomitus, total mercury contents were in the order of soil $>$ earthworms $>$ earthworm vomitus. Methyl mercury was about $3.01 \%$ of total mercury in Drawida sp., $12.02 \%$ of total mercury in Alolobophora sp.,
\end{abstract}

\footnotetext{
Z. S. Zhang · Q. C. Wang · X. G. Lv (ه)

Key Laboratory of Wetland Ecology and Environment, Institute of Northeast Geography and Agroecology, Chinese Academy of Science, 130012 Changchun, People's Republic of China

e-mail: luxg@neigae.ac.cn

\section{Z. S. Zhang}

Graduate University of Chinese Academy of Sciences, 100049 Beijing, People's Republic of China

e-mail: zzslycn@163.com

\section{M. Zheng}

Key Laboratory of Eco-Remediation of Contaminated Environment and Resource Reuse, Shenyang University, 110044 Shenyang, People's Republic of China
}

respectively. It suggested that mercury was mostly in inorganic forms in earthworms. Bioaccumulation factors of methyl mercury from soil to earthworms were much higher than those of total mercury, which suggested that methyl mercury might be more easily absorbed by and accumulated in earthworms because of its lipid solubility.

Keywords Earthworm - Total mercury .

Methyl mercury · Bioaccumulation factor · China

Earthworms constitute a major component in soil ecosystem and are the representative species of soil animals with the largest terrestrial faunal biomass. Earthworms play important roles in element geochemistry cycle since they contribute to organic matter incorporation and decomposition. Earthworms are easily influenced by pollutants in soil such as metals, organic pollutants and so on. In field, with their limit mobility, earthworms are very suitable for monitoring the effects of contaminations. In recent years, many studies have focused on the acute toxicity effects to earthworms of inorganic and organic pollutants such as the nickel, oil, and so on (Vandecasteele et al. 2004; Koen and Colin 2002; Cortet et al. 1999). There are also many researches concerning heavy metals accumulation in earthworms and most are on cadmium, zinc, and lead (Kamitani and Kaneko 2007; Vliet et al. 2005; Ma 2004). Few data are available on total and methyl mercury concentrations in earthworms (Burton et al. 2006).

Mercury has been recognized as a very toxic metal in the environment and poses a serious threat to health of wild mammals, birds and human due to the fact that it can be biomagnified along food chains (Boening 2000). Earthworms have the largest biomass among the soil invertebrates and they provide the import protein source for many small 
mammals like shrews (Hendriks et al. 1995). Hsu et al. (2006) claimed that levels and the bioconcentration factors of mercury in earthworms were very high. Since earthworms are the essential components in many food chains, healths of animals feeding on earthworms and occupying the high trophic level might be seriously threatened due to mercury transferring along the food chain.

The study area of this paper is the Hulucao City, which locates in Liaoning Province, and it is an important nonferrous smelting and chemical industry area in northeast China. Mercury contents in soil, water, plants and crops are high due to the pollutants discharged during metal and caustic soda producing process (Zheng et al. 2007). Wuli River and Cishan River are two main rivers in the city. In the past few decades, waste water contaminated with heavy metals had been discharged into the Wuli and Cishan Rvier by a chlor-alkali plant and zinc smeltery, respectively. The Cishan River also has been impacted by the dry deposition of metal-contaminated particular matter from the zinc smeltery up to date.

In this paper, we analyzed total and methyl mercury contents in soil and three earthworm species collected from sites suffering mercury pollution from pollution by zinc smelting and chlor-alkali production. Bioaccumulation factors (BAF) were applied to discuss the mercury biomagnification from soil to earthworms so as to understand the mercury biogeochemistry cycle in soil ecosystem.

\section{Materials and Methods}

Three earthworm species, Drawida sp., Allolobophora sp. and Limnodrilus sp. were collected from the Huagong
Bridge (S1), Longwan Bridge (S2), Wastewater treatment plant (S3) and Daochi Village (S4) by hands in June, 2006 (Fig. 1). Earthworms were kept in soil collected from the same site in brown glass jars in field and brought back to laboratory. Earthworms were picked out with forceps, thoroughly rinsed with distilled water as soon as possible, and put into the brown jars with one filter paper in, and a few drops of distilled water were added to maintain them moist. Earthworms were kept at room temperature (about $16^{\circ} \mathrm{C}$ ) for $7 \mathrm{~d}$ to empty their guts, then weighted, counted and identified, and their body lengths were measured. Earthworms were oven dried $\left(48 \mathrm{~h}\right.$ at $\left.60^{\circ} \mathrm{C}\right)$ to constant weights, ground to homogeneous powder in a quartz bowl, and preserved in polythene bags in refrigerator at $-4^{\circ} \mathrm{C}$ before used. Soil and earthworm vomitus evacuating from their guts were dried at room temperature, ground to pass an 80-mesh sieve and preserved in polythene bags before used.

Total mercury in soil, earthworms and their vomitus were extracted following the method of $\mathrm{H}_{2} \mathrm{SO}_{4}-\mathrm{HNO}_{3}-$ $\mathrm{V}_{2} \mathrm{O}_{5}$ (Liu et al. 2003). All speciation of mercury were converted to $\mathrm{Hg}^{2+}$ and then $\mathrm{Hg}^{2+}$ was reduced to elemental $\mathrm{Hg}$ by addition of $20 \% \mathrm{SnCl}_{2}$ solution. Cold atomic absorption technique was used to determine the concentrations of total $\mathrm{Hg}$ with an $\mathrm{F} 732 \mathrm{-V} \mathrm{Hg}$ analyzer with a detection limit of $0.05 \mathrm{ng} / \mathrm{g}$.

Methyl mercury in earthworms and soil were extracted and separated using the modified method described by Sun et al. (2007). $0.500 \mathrm{~g}$ of soil or earthworm samples was weighted and put into a $50 \mathrm{~mL}$ polyethylene centrifuge tube. About $5.0 \mathrm{~mL} \mathrm{HCl}(6.0 \mathrm{~mol} / \mathrm{L})$ was added to extract all forms of mercury. The tube was placed overnight and then ultrasonically cleaned for $2 \mathrm{~h}$ by the Ultrasonic Leaner Instrument (Kunshan Ultrasonic Cleaner Instrument Co.,

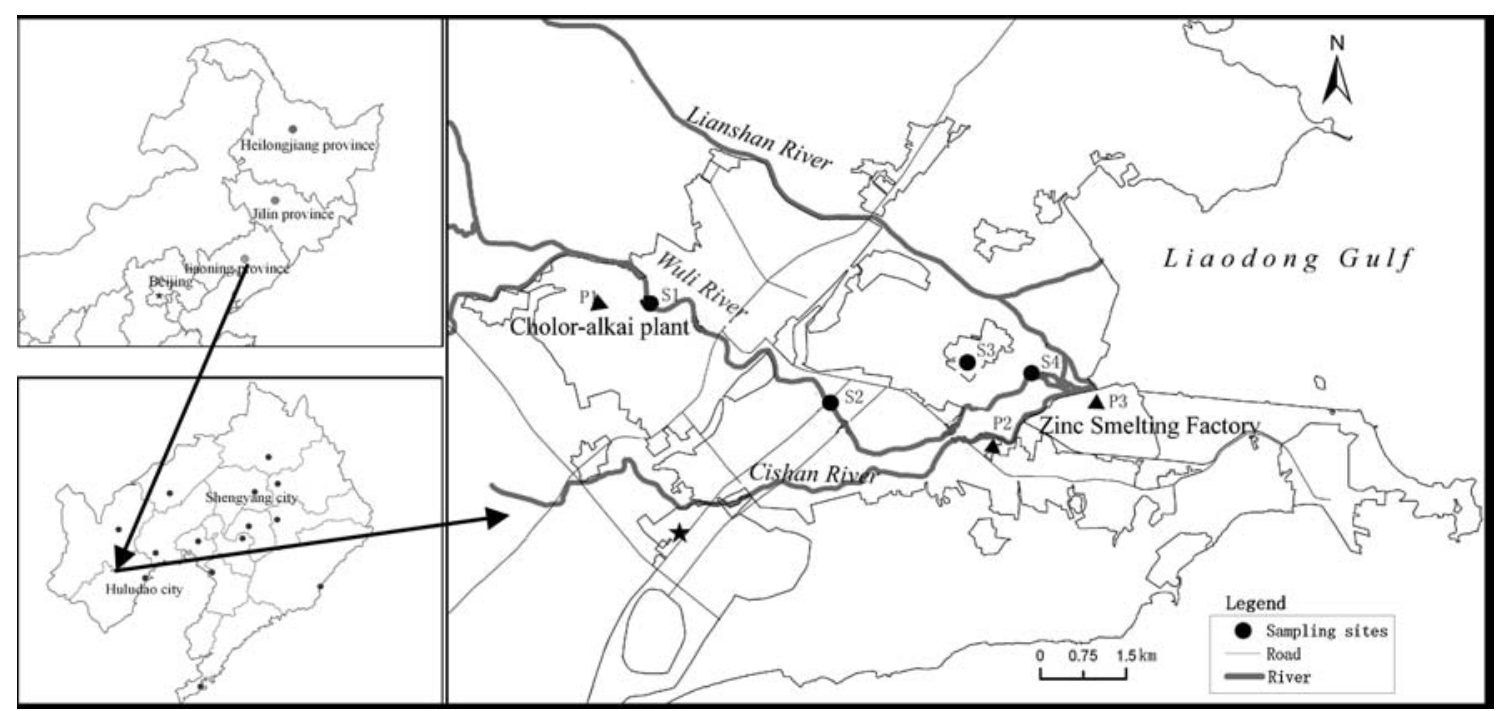

Fig. 1 Sample sites (S1, Huagong Bridge; S2, Longwan Bridge; S3, Wastewater Treatment Plant; S4, Daochi Village; P1, Chlor-alkali Plant; P2, Privately owned Zinc Smeltery; P3, State-owned Zinc Smeltery) 
Ltd., China). After that, the tube was centrifugated at $3000 \mathrm{rpm}$ for $15 \mathrm{~min}$. The supernatant fluid was transferred into a $10 \mathrm{~mL}$ polyethylene centrifuge tube; $2.0 \mathrm{~mL}$ of $\mathrm{CH}_{2} \mathrm{Cl}_{2}$ was added and shaken for $1 \mathrm{~h}$ to extract organomercury compounds into the $\mathrm{CH}_{2} \mathrm{Cl}_{2}$ phase. After centrifuging at $3000 \mathrm{rpm}$ for $15 \mathrm{~min}$, the $\mathrm{CH}_{2} \mathrm{Cl}_{2}$ phase was transferred into a $50 \mathrm{~mL}$ glass tube; an additional $2.0 \mathrm{~mL}$ of $\mathrm{CH}_{2} \mathrm{Cl}_{2}$ was added into the $10 \mathrm{~mL}$ polyethylene centrifuge tube again to remove any remaining methyl mercury. The same procedure was repeated. Finally, $5.0 \mathrm{~mL}$ deionized water was added into the $50 \mathrm{~mL}$ glass tube, which had contained the $4.0 \mathrm{~mL} \mathrm{CH}_{2} \mathrm{Cl}_{2}$ phase. The $50 \mathrm{~mL}$ glass tube was placed in a $60^{\circ} \mathrm{C}$ water bath and was aerated by $\mathrm{N}_{2}$. The $\mathrm{CH}_{2} \mathrm{Cl}_{2}$ was blown off and the organomercury compounds were left in the water phase. At last, $1.0 \mathrm{~mL}$ $\mathrm{H}_{2} \mathrm{SO}_{4}(18.0 \mathrm{~mol} / \mathrm{L})$ and $1.0 \mathrm{~mL}$ bromide agent $\left(\mathrm{KBrO}_{3}+\right.$ $\mathrm{KBr}$ ) were added into the $50 \mathrm{~mL}$ glass tube, which played the role of oxidation and indicator, respectively. After $1 \mathrm{~h}$, a drop of hydroxylamine hydrochloride was added into the tube to deoxidize the residual bromide agent. The methyl mercury was determined by Tekran Model 2600 (330 Nantucket Boulevard, Toronto, Ontario), which was stable and the recoveries of methyl mercury were between 94.1\%-102.3\%.

Calibration standards and blanks were analyzed with each batch of samples. The determined accuracy was verified by the environmental standard reference material of soil sample (GBW 07405) and the material IAEA-443. The expected total and methyl mercury contents in GBW07405 and IAEA-443 were $(0.29 \pm 0.003) \mathrm{mg} / \mathrm{kg}$ and $(0.17 \pm$ $0.07) \mathrm{mg} / \mathrm{kg}$, respectively. The corresponding measured results were $(0.29 \pm 0.015) \mathrm{mg} / \mathrm{kg}$ and $(0.15 \pm 0.03) \mathrm{mg} /$ $\mathrm{kg}$, respectively. Blanks were used to ensure the purity of chemical reagents and revise the concentrations of the measured samples. The method detection limit for methyl mercury was $0.1 \mathrm{pg} / \mathrm{g}$.

The BAF of the total and methyl mercury in the earthworms were calculated by the following formula: BAF = total (or methyl) mercury contents in the earthworms/total (or methyl) mercury contents in the soil.

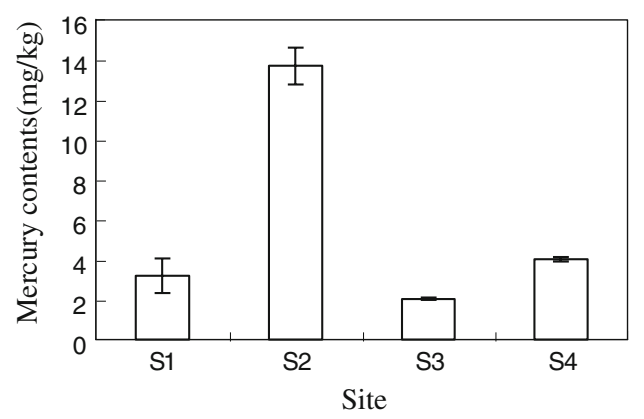

SPSS version 10.0 and Excel 2003 were used for data statistical analysis. One-way ANOVA was used to determine signification differences between species. ArcGIS version9.0 was used for map sample sites.

\section{Results and Discussion}

Total mercury contents in soil ranged from 2.04 to $15.23 \mathrm{mg} / \mathrm{kg}$ with the average value of $7.20 \mathrm{mg} / \mathrm{kg}$. Methyl mercury contents in soil ranged from 2.01 to $10.38 \mathrm{ng} / \mathrm{g}$ with the average value of $6.94 \mathrm{ng} / \mathrm{g}$. In the four sites, the highest total mercury content was found in Longwan Bridge (S2), and the highest methyl mercury content was observed in Huagong Bridge (S1) (Fig. 2). Total mercury contents showed no significant correlation with methyl mercury in soil $(r<0.50, p>0.05)$.

Longwan Bridge (S2) located in the lower reaches of Wuli River, and a large amount of mercury brought by wastewater discharged from the upstream precipitated here and resulted in high mercury levels in the surface sediment and soil. The past effluent outlet of the chloralkali plant located in Huagong Brige (S1), and the surface sediment here contained many complex organic compounds, which might accelerate mercury methylation induced by bacterium and microorganisms. Wastewater treatment plant (S3) and Daochi Village (S4) are both influenced by the zinc smelting plant around and high mercury levels here were attributed to the dry deposition of metal contaminated particulate matter from the zinc smeltery.

Total mercury contents in earthworms' vomitus ranged from 0.163 to $2.389 \mathrm{mg} / \mathrm{kg}$ (mean, $0.966 \mathrm{mg} / \mathrm{kg}$ ) in Drawida sp., from 1.470 to $12.274 \mathrm{mg} / \mathrm{kg}$ (mean, $4.979 \mathrm{mg} / \mathrm{kg}$ ) in Allolobophora sp. respectively. ANOVA analysis indicated that total mercury contents in vomitus of Drawida sp. and Allolobophora sp. were significantly different $(F=13.811$, $p=0.001)$. Compared with total mercury contents in soil, mercury in earthworms' vomitus was lower (Table 1). It suggested that parts of mercury, which were attached in the

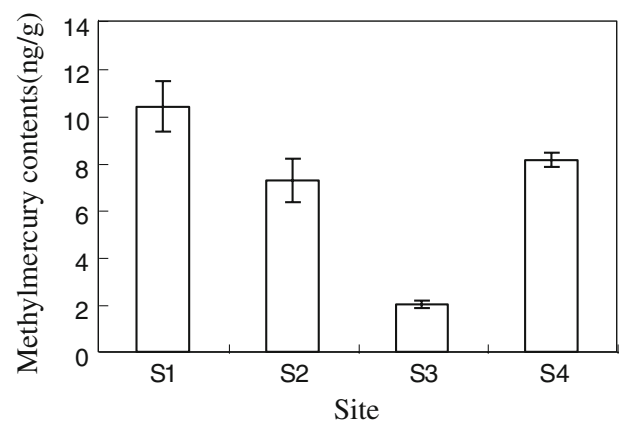

Fig. 2 Total and methyl mercury contents in soil in different sample sites 
Table 1 Total mercury contents in earthworms' vomitus with different body length

\begin{tabular}{|c|c|c|c|c|}
\hline \multirow[t]{2}{*}{ Site } & \multirow[t]{2}{*}{ Earthworm species } & \multicolumn{3}{|c|}{ Total mercury contents in vomitus $(\mathrm{mg} / \mathrm{kg})$} \\
\hline & & $<10 \mathrm{~cm}$ & $10-15 \mathrm{~cm}$ & $15-20 \mathrm{~cm}$ \\
\hline \multirow[t]{2}{*}{ (S1) Huagong Bridge } & Drawida sp. & 1.580 & 0.531 & 0.407 \\
\hline & Allolobophora sp & 2.863 & 2.147 & \\
\hline \multirow[t]{2}{*}{ (S2) Longwan Bridge } & Drawida sp. & 2.308 & 0.436 & 0.170 \\
\hline & Allolobophora sp. & 5.667 & 8.886 & \\
\hline (S3) Wastewater treatment plant & Limnodrilus sp. & 0.096 & & \\
\hline \multirow[t]{2}{*}{ (S4) Daochi Village } & Drawida sp. & 2.389 & & \\
\hline & Allolobophora sp. & & 2.450 & 1.470 \\
\hline
\end{tabular}

organic matter or the microorganisms and ingested by earthworms, were assimilated in their guts.

On the whole, total mercury contents in earthworms' vomitus were different by and in decreasing with earthworm body lengths (Table 1). The extent of decrease in Drawida sp. was larger than that in Allolobophora sp.

Total mercury contents ranged from 0.8 to $2.21 \mathrm{mg} / \mathrm{kg}$ (mean $1.43 \mathrm{mg} / \mathrm{kg}$ ) in Drawida sp.; from 1.17 to $5.46 \mathrm{mg} /$ $\mathrm{kg}$ (mean $2.80 \mathrm{mg} / \mathrm{kg}$ ) in Allolobophora sp., respectively. Total mercury contents in these three earthworms were in the order of Allolobophora sp. $>$ Drawida sp. $>$ Limnodrilus sp. with significant difference $(F=6.272, p=0.026)$. Neither in Drawids sp. nor in Allolobophora sp. did total mercury much varied largely with body lengths (Table 2).

Methyl mercury contents ranged from 13.48 to $103.68 \mathrm{ng} /$ g (mean, $43.03 \mathrm{ng} / \mathrm{g}$ ) in Drawida sp., from 124.20 to $877.10 \mathrm{ng} / \mathrm{g}$ (336.52 ng/g) in Alolobophora sp., respectively. Methyl mercury contents were not significantly different between in Drawida sp. and in Alolobophora sp.

On the whole, percents of methyl mercury to total mercury were about $3.01 \%$ in Drawida sp. and $12.02 \%$ in Alolobophora sp., respectively. It indicated that mercury were almost in inorganic forms in the two earthworm species. These percents in earthworms were lower than in insects collected from the same site. For example, methyl mercury was about $40 \%$ of total mercury in Locusta migratoria manilensis (Zheng et al. 2008).
Different from the inapparent trend of total mercury contents decreasing with body lengths, methyl mercury generally was more obvious. Results suggested that methyl mercury was high and more easily absorbed by earthworms when they were young, and then in decreasing with their growth and development. This result might due to the growth dilution, which resulted in both total and methyl mercury decreasing with earthworm body lengths though they could assimilate more mercury amounts after growing up.

Earthworms contribute to more than $90 \%$ of the soil invertebrate biomass and are considered suitable for studying and monitoring mercury bioaccumulation in the soil ecosystems. Many researchers reported that heavy metals were easily assimilated by earthworms, such $\mathrm{Cu}, \mathrm{Pb}$, $\mathrm{Zn}, \mathrm{Cd}$ and so on. Ernst and Frey (2007) testified that mercury in earthworms mostly came from soil through a microcosm experiment. Bioaccumulation factor (BAF) was applied to study the mercury accumulation in the soilearthworm system in the present research (Table 3). Results showed that $\mathrm{BAF}_{\mathrm{m}}$ was much higher than $\mathrm{BAF}_{\mathrm{t}}$, which suggested that methyl mercury might be more easily absorbed by earthworms because of its lipid solubility.

In recent years, many researches have focused on heavy metals accumulation in earthworms and their relationships with total and bioavailable fractions in soil, and reported that metals in earthworms were significantly related to

Table 2 Total and methyl mercury contents in earthworms with different body lengths

\begin{tabular}{|c|c|c|c|c|c|c|c|}
\hline \multirow[t]{2}{*}{ Site } & \multirow[t]{2}{*}{ Species } & \multicolumn{3}{|c|}{ Total mercury in earthworms (mg/kg) } & \multicolumn{3}{|c|}{ Methyl mercury in earthworms (ng/g) } \\
\hline & & $<10 \mathrm{~cm}$ & $10-15 \mathrm{~cm}$ & $15-20 \mathrm{~cm}$ & $<10 \mathrm{~cm}$ & $10-15 \mathrm{~cm}$ & $15-20 \mathrm{~cm}$ \\
\hline \multirow[t]{2}{*}{ (S1) Huagong Bridge } & Drawida sp. & 1.380 & 1.215 & 1.229 & 103.68 & 13.48 & 19.96 \\
\hline & Allolobophora sp & 1.240 & 1.175 & & 877.10 & 125.11 & \\
\hline \multirow[t]{2}{*}{ (S2) Longwan Bridge } & Drawida sp. & 2.212 & 1.521 & 5.560 & 38.75 & 39.29 & \\
\hline & Allolobophora sp. & 3.148 & 2.889 & & 219.68 & 124.20 & \\
\hline (S3) Wastewater treatment plant & Limnodrilus sp. & 0.082 & & & & & \\
\hline \multirow[t]{2}{*}{ (S4) Daochi Village } & Drawida sp. & 1.165 & 1.016 & & & & \\
\hline & Allolobophora sp. & 1.712 & 1.695 & 0.670 & & & \\
\hline
\end{tabular}


Table 3 Bioaccumualtion factors of earthworm in different sites

\begin{tabular}{lllr}
\hline Sites & $\begin{array}{l}\text { Average total mercury } \\
\text { in earthworms (mg/kg) }\end{array}$ & $\begin{array}{l}\text { Average methyl mercury } \\
\text { in earthworms (ng/g) }\end{array}$ & BAF $_{\mathrm{t}}^{\mathrm{a}}$ \\
\hline (S1) Huagong Bridge & 1.256 & 105.48 & 10.163 \\
(S2) Longwan Bridge & 2.806 & 227.87 & 31.387 \\
(S3) Wasterwater treatment plant & 0.082 & & 0.539 \\
(S4) Daochi Village & 1.173 & & 0.203 \\
\hline
\end{tabular}

${ }^{a}$ Bioaccumulation factors of total mercury

b Bioaccumulation factors of methyl mercury

fractions extracted out by DTPA (Dai et al. 2004; Hobbelen et al. 2006). But methyl mercury was complexly associated with clays, humus and other substances in soil, and might not be selectively and thoroughly extracted out just by $\mathrm{CaCl}_{2}$ or DTPA and it is still unclear whether methyl mercury is directly absorbed from soil by earthworms or methyl mercury is transformed by inorganic mercury in earthworm bodies. It is meaningful to study the methyl mercury bioaccumulation and transformation processes from soil to earthworms in details.

In this field study, we have shown that earthworms accumulated a large amount of mercury in the polluted soil. Both total and methyl mercury of the Allolobophora sp. were higher than Drawida sp. With growth and development, total and methyl mercury were both generally in decreased with earthworm body lengths on the whole. Among the soil, earthworms and their vomitus, total mercury contents were in the order of soil $>$ earthworms $>$ earthworm vomitus. Compared with total mercury, methyl mercury contents in earthworms were about $3.01 \%$ in Drawida sp. and $12.02 \%$ in Alolobophora sp., respectively. It suggested that mercury was mostly in inorganic forms in earthworm bodies. The bioaccumulation factors showed that methyl mercury was more easily accumulated in earthworms.

Acknowledgements This work was financially supported by the National Nature Science Foundation of China (40830535), Major State Basic Research Projects of China (2009CB42110303) and the Innovation Foundation of Chinese Academy of Sciences (KZCX3SW-437). Authors thank Professor Wang G.P. for his suggestions on English syntax and grammar.

Open Access This article is distributed under the terms of the Creative Commons Attribution Noncommercial License which permits any noncommercial use, distribution, and reproduction in any medium, provided the original author(s) and source are credited.

\section{References}

Boening DW (2000) Ecological effects, transport, and fate of mercury: a general review. Chemosphere 40:1335-1351. doi: 10.1016/S0045-6535(99)00283-0
Burton DT, Turley SD, Fisher DJ, Green DJ, Shedd TR (2006) Bioaccumulation of total mercury and menomethylmercury in the earthworm Eisenia Fetida. Water Air Soil Pollut 170:37-54. doi:10.1007/s11270-006-3113-0

Cortet J, Vauflery AG-D, Poinsot-Balaguer N, Gomot L, Texier C, Cluzeau D (1999) The use of invertebrate soil fauna in monitoring pollutant effects. Eur J Soil Biol 35:115-134. doi: 10.1016/s1164-5563(00)00116-3

Dai J, Becquer T, Rouiller JH, Reversat G, Bernhard-Reversat F, Nahmani J, Lavelle P (2004) Heavy metal accumulation by two earthworm species and its relationship to total and DTPAextractable metals in soils. Soil Biol Biochem 36:91-98. doi: 10.1016/j.soilbio.2003.09.011

Dorn PB, Vipond TE, Salanitro JP, Wisniewski HL (1998) Assessment of the acute toxicity of crude oils in soils using earthworms, microtox ${ }^{\circledR}$, and plants. Chemoshpere 37:845-860. doi:10.1016/S0045-6535(98)00089-7

Ernst G, Frey B (2007) The effect of feeding behavior on $\mathrm{Hg}$ accumulation in the ecophysiologicaly different earthworms Lumbricus terrestris and Octolaseon cyaneum: a microcosm experiment. Soil Biol Biochem 39:386-390. doi:10.1016/j. soilbio.2003.09.001

Hendriks AJ, Ma WC, Brouns JJ, Ruiter-Dijkman EM, Gast R (1995) Modelling and monitoring organochlorine and heavy metal accumulation in soils, earthworms, and shrews in Rhine-Delta floodplains. Arch Environ Contam Toxicol 29:115-127. doi: 10.1007/BF00213096

Hobbelen P, Koolhaas J, Gestel C (2006) Bioaccumualtion of heavy metals in the earthworms Lumbricus rubellus and Aporrectodea caliginosa in relation to total and available metal concentrations in field soils. Environ Pollut 144:639-646. doi:10.1016/j.envpol. 2006.01.019

Hsu MJ, Selvaraj K, Agoramoorthy G (2006) Taiwan's industrial heavy metal pollution threatens terrestrial biota. Environ Pollut 143:327-334. doi:10.1016/j.envpol.2004.11.023

Kamitani T, Kaneko N (2007) Species-specific heavy metal accumulation patterns of earthworms on a floodplain in Japan. Ecotoxicol Environ Saf 66:82-91. doi:10.1016/j.ecoenv.2005.10.009

Koen L, Colin RJ (2002) Ecotoxicity of nickel to Eisenia fetida, Enchytraeus albidus and Folsomia candida. Chemosphere 46:197-200. doi:10.1016/S0045-6535(01)00112-6

Liu RH, Wang QC, Lu XG, Fang FM, Wang Y (2003) Distribution and speciation of mercury in the peat bog of Xioaxing'an Mountain, Northeastern China. Environ Pollut 124:36-46. doi: 10.1016/S0269-7491(02)00432-3

Ma WC (2004) Estimating heavy metal accumulation in Oligochaete earthworms: a meta-analysis of field data. Bull Environ Contam Toxicol 72:663-670. doi:10.1007/s00128-004-0296-1

Sun J, Chen CY, Li YF, Li B, Gao YX, Chai ZF (2007) Rapid analysis of methylmercury and total mercury in biological samples by ultransonic-assisted solvent extraction coupled with 
inductively coupled plasma-mass spectrometry. Spectrosc Spectr Anal 27:173-176 (in Chinese)

Vandecasteele B, Samyn J, Quataert P, Muys B, Tack FMG (2004) Earthworm biomass as additional information for risk assessment of heavy metal biomagnification: a case study for dreddged sediment-derived soils and polluted floodplain soils. Environ Pollut 129:363-375. doi:10.1016/j.envpol.2003.12.007

Vliet P, Zee S, Ma WC (2005) Heavy metal concentrations in soil and earthworms in a floodplain grassland. 138:505-516. doi:10.1016/ j.envpol.2005.04.010
Zheng N, Wang QC, Zheng DM (2007) Health risk assessment of heavy metals to residents by consuming vegetable irrigated around zinc smelting plant based THQ. Acta Scientiae Circumstantiae 27:672-678 (in Chinese)

Zheng DM, Wang QC, Zhang ZS, Zheng N, Zhang XW (2008) Bioaccumulation of total and methyl mercury by arthropods. Bull Environ Contam Toxicol 81:95-100. doi:10.1007/s00128008-9393-x 